\title{
Assessment of tomato and wine processing solid wastes as soil amendments for biosolarization
}

\author{
Yigal Achmon ${ }^{1,2}$, Duff R. Harrold ${ }^{2}$, Joshua T. Claypool ${ }^{2}$, James J. Stapleton ${ }^{3}$, Jean S. \\ VanderGheynst ${ }^{2}$, and Christopher W. Simmons ${ }^{1} *$
}

${ }^{1}$ Department of Food Science and Technology, University of California, One Shields Ave., Davis, CA 95616, United States

${ }^{2}$ Department of Biological and Agricultural Engineering, University of California, One Shields Ave., Davis, CA 95616, United States

${ }^{3}$ Statewide Integrated Pest Management Program, University of California, Kearney Agricultural Research and Extension Center, Parlier, CA 93648, United States

* Corresponding author. Tel.: +1 530752 2109. E-mail address: cwsimmons@ucdavis.edu. 


\section{ABSTRACT}

2 Pomaces from tomato paste and wine production are the most abundant fruit processing residues

3 in California. These residues were examined as soil amendments for solarization to promote

4 conditions conducive to soil disinfestation (biosolarization). Simulated biosolarization studies

5 were performed in both aerobic and anaerobic soil environments and soil temperature elevation,

$6 \mathrm{pH}$, and evolution of $\mathrm{CO}_{2}, \mathrm{H}_{2}$ and $\mathrm{CH}_{4}$ gases were measured as metrics of soil microbial activity.

7 Tomato pomace amendment induced conditions associated with soil pest inactivation, including

8 elevation of soil temperature by up to $2{ }^{\circ} \mathrm{C}$ for a duration of 4 days under aerobic conditions and a

9 reduction of soil $\mathrm{pH}$ from 6.5 to 4.68 under anaerobic conditions. White wine grape pomace

10 amendment showed similar trends but to a lesser extent. Red wine grape pomace was generally

11 less suitable for biosolarization due to significantly lower soil temperature elevations, reduced

12 acidification relative to the other pomaces and induction of methanogenesis in the soil.

14 Keywords: Solarization, tomato pomace, wine grape pomace, food and beverage processing

15 wastes, sustainable agriculture, anaerobic soil disinfestation, soil respiration, soil fumigant

16 alternative. 
Soil treatment to inactivate soil-borne pathogens and pests is an important practice in modern agriculture (Popp et al., 2013). Most pest management soil treatments use synthetic chemicals to destroy pathogens and weeds pre- or post-emergence (Lichtfouse et al., 2009). However, soil fumigants, such as methyl bromide, can have a deleterious effect on the environment (Maione et al., 2013). In contrast, alternative and sustainable integrated pest management strategies can be both environmentally friendly and cost effective (Lichtfouse et al., 2009). One such practice that has already seen practical application is solarization (Katan and DeVay, 1991), which employs solar heating to inactivate soil-borne pathogens, nematodes, and weed propagules. During solarization, moist soil is covered with transparent plastic tarp to induce passive solar heating of the soil and thermal inactivation of pests. Solarization has been successfully implemented in strawberry cultivation (Yildiz et al., 2010) and in smaller farming operations (Stapleton et al., 2005). Hurdles preventing widespread use of solarization include a strict scheduling requirement to coincide with the warmest period of the year and the variable efficacy of inactivation (Stapleton, 2000).

To address these issues, soil microbial activity enhanced by organic soil amendments has been combined with solarization, in a process termed biosolarization, to increase heat accumulation in the soil and produce chemical factors, including organic acids and other decomposition products, for pathogen and weed seed inactivation (Gamliel and Stapleton, 1993a; Huang et al., 2014; Momma et al., 2006). It is thought that the combination of multiple inactivation mechanisms during biosolarization may enhance pest inactivation and compensate for suboptimal climates that are not ideal for passive solar heating alone (Butler et al., 2014; Lamers et al., 2014). Biosolarization has been 
effective in controlling nematodes and other soil-borne pathogens in Japan, the Netherlands, and the US (Lamers et al., 2014).

Biological contributions to pest inactivation during biosolarization depend, in part, on the ability of soil microbial communities to convert soil organic matter into relevant

biotoxic end products. Green waste compost has been demonstrated as an effective inoculum for introducing thermophilic bacteria to the soil that remain active under the extreme conditions encountered during biosolarization (Simmons et al., 2013). Additionally, some organic matter sources have already been shown to be compatible with biosolarization, such as chicken manure (López-Pérez et al., 2005), cruciferous, alliaceous, and poaceous crop residues (Gamliel and Stapleton, 1993a; Mallek et al., 2007; Stapleton et al., 2010), wheat bran (Simmons et al., 2014), and others. However, these amendments represent only a narrow fraction of the potential organic matter sources that might be used for biosolarization. As a result, there is a need to assess the biosolarization potential of a broad range of organic amendments, particularly abundant, low-value organic waste streams that could enable widespread adoption of biosolarization.

Solid residues from fruit processing are promising biosolarization soil amendments due to the fact that many of them are rich in organic compounds and have few alternate uses. As a major agricultural and food processing hub for the USA and the world, California produces large quantities of fruit processing residues and requires soil pest management in high-value, horticultural crops. The most abundant fruit processing solid residues in California are pomaces from tomato paste and wine production (Matteson and Jenkins, 2007). Pomace consists primarily of skins and seeds that remain after the fruit has been disrupted and pressed. For grape pomace, pomace comes from both white wine production, where the juice is separated from the pomace ahead of 
fermentation, and red wine production, where the pomace is separated from juice after fermentation. As tomato and grape pomaces contain appreciable levels of carbohydrates (Del Valle et al., 2006; Valiente et al., 1995), they justify investigation as possible substrates for soil microogranisms during biosolarization.

In this study, the biosolarization potential of tomato pomace and red- and whitewine grape pomace were investigated using a bioreactor-based, simulated biosolarization approach. Metrics relevant to pest inactivation, such as soil heating and acidification, were measured under aerobic and anaerobic soil conditions. Additionally, evolution of carbon dioxide, hydrogen, and methane gases were measured as indicators of microbial activity, substrate utilization, and potential greenhouse gas emissions. This simulated solarization technique has been shown to yield estimations of microbial soil activity that translate well to biosolarization field trials (Simmons et al., 2013). Relative to field conditions, simulated biosolarization in a laboratory setting permits finer control of process variables for comparing the biosolarization potential of different materials under varying conditions. Furthermore, it can serve as a decision making tool for identifying soil organic amendments, such as organic wastes from agriculture and food processing, that warrant further study in more resource-intensive field trials.

\section{Materials and Methods}

\subsection{Soil and soil amendments}

Soil was collected from the Kearney Agriculture Research and Extension Center located in Parlier, CA in September, 2014 (36.6 $\mathrm{N}$; 119.5 W; elevation $97 \mathrm{~m})$. Mature green waste compost (from composting of lawn clippings, branches, and leaves) was obtained from a commercial facility in Zamora, CA in 2011. Tomato pomace was 
collected from a commercial tomato paste production facility in California in September, 2014. Red- and white-wine grape pomaces were obtained from the teaching winery at the University of California, Davis, in October, 2014. Properties of each material are given (Table 1). All pomaces were initially solar dried and then dried to their final storage moisture content in a drying oven $\left(55^{\circ} \mathrm{C}\right.$ for $3-5$ days $)$. Each pomace was ground in a laboratory blender to achieve particle sizes $<1 \mathrm{~mm}$ prior to analysis. Moisture content were determined gravimetrically (Pansu and Gautheyrou, 2007). Briefly, samples of tomato pomace, grape pomace, compost, and soil were weighed prior to and following drying in a vacuum oven once the dry weight for each stabilized. Determination of water holding capacity (WHC) was performed as previously described (McConnell et al., 1974) with several modifications. Samples of pomace and compost weighing 3-5 grams were placed in $15 \mathrm{~mL}$ plastic centrifuge tubes. An excess of distilled water was added to the samples and they were allowed to equilibrate for $24 \mathrm{hr}$. After reaching saturation, solids were isolated by centrifugation for $10 \mathrm{~min}$ at $9000 \mathrm{rpm}$. The supernatant was decanted and residual water was removed by gently blotting with tissue to avoid loss of solids. The weight of the saturated material was used in conjunction with the dry weight to calculate WHC. Soil WHC was determined by wetting 3 grams of soil on filter paper to saturation with distilled water, allowing excess water to drain over $48 \mathrm{hr}$, and then comparing wet and dry sample weights as described previously. Volatile solids content was determined as the difference between the dry weight of each sample and the sample weight following incineration at $550^{\circ} \mathrm{C}$ for $7 \mathrm{hr}$. Values of $\mathrm{pH}$ were measured on mixtures of soil, compost, or pomace combined with distilled water at a 1:1 ratio. Bulk density was determined by weighing 5-mL samples of dried material and calculating the weight to volume ratio. 
To prepare amended soil for bioreactor experiments, soil aliquots were combined with compost and pomace to achieve $2 \%$ and $5 \%$ loading (dry weight basis), respectively. Four soil amendment treatments were considered: soil containing $2 \%$ green waste compost and $5 \%$ tomato pomace, soil containing $2 \%$ green waste compost and $5 \%$ white wine grape pomace, soil containing $2 \%$ green waste compost and $5 \%$ red wine grape pomace, and a negative control consisting of soil containing $2 \%$ compost without pomace amendment. Dry soil and amendment materials were thoroughly mixed and then wetted with distilled water to achieve $80 \%$ WHC to represent the near-saturation conditions in field soil during biosolarization. Properties of soil mixtures are provided (Table 2).

\subsection{Simulated biosolarization}

Two bioreactor systems were established to broadly represent the aeration extremes that may be encountered in soil during biosolarization (Fig. 1). These include an anaerobic system to simulate conditions that may occur deeper in the soil or in those with high clay and/or moisture contents where oxygen diffusion is low, and an aerobic system to replicate soil conditions that could occur near the soil surface or in sandier soils as a result of oxygen diffusion from untarped border regions or through the tarp itself. For the anaerobic system, $250 \mathrm{~mL}$ glass media bottles with lids modified to accept a check valve (catalog \#80103, Qosina, Edgewood, NY) were used as bioreactors. These reactors allowed evolved gases to escape the reactor headspace while preventing oxygen contamination. Tubing attached to the check valve and connected to a separate $250 \mathrm{~mL}$ bottle served as a gas collector (Fig. 1). Gas collectors for each reactor were connected to a MicroOxymax respirometry system (Columbus Instruments, Columbus, $\mathrm{OH}$ ) equipped with infrared absorbance sensors for measurement of methane and carbon dioxide and an 

gases in collectors occurred every two hours.

For the aerobic system, 250-mL aerated bioreactors described previously (Simmons et al., 2013) were used with several modifications. To reduce cooling and drying of the soil, air was heated and humidified to saturation by bubbling it through a series of three $1 \mathrm{~L}$ glass bottles upstream of the bioreactors containing distilled water at $55^{\circ} \mathrm{C}$. Effluent gas from each bioreactor was fed through glass bottles at room temperature to condense moisture and protect sensors downstream. During operation, reactors were supplied with air at a rate of $20 \mathrm{~mL} / \mathrm{min}$. Carbon dioxide concentrations in both reactor influents and effluents were measured using an infrared absorbance $\mathrm{CO}_{2}$ sensor (Vaisala, Suffolk, UK) and the mass flow-rate through the reactors was measured using a mass-flow meter (Aalborg, Orangeburg, NY).

All reactors were loaded with $100 \mathrm{~g}$ dry weight of wetted amended soil and were incubated at $55^{\circ} \mathrm{C}$ in a temperature-controlled incubator for the duration of simulated biosolarization as previously described (Simmons et al., 2013). This temperature represents the extreme level that soil microorganisms are likely to encounter at approximately $15 \mathrm{~cm}$ depth during biosolarization in the field (Katan, 1981) and was selected to gauge whether soil organic amendments could be biologically degraded under high thermal stress. Additionally, all reactors were jacketed with closed cell foam insulation (thermal conductivity of $0.04 \mathrm{~W} / \mathrm{m} \cdot \mathrm{K}$ ) to reduce convective cooling through the reactor walls (Fig. 1) and promote one-dimensional heat transfer from the soil surface to better mimic the insulating effect of surrounding soil in the field. Miniature temperature sensors and data loggers (Thermochron iButtons model 1922L, Embedded Data Systems, 
and four replicate reactors were used for each treatment in the anaerobic and aerobic systems, respectively. At the conclusion of simulated biosolarization ( 2 to 3 weeks of incubation to exhaust $\mathrm{CO}_{2}$ production), soil samples from each reactor were taken for $\mathrm{pH}$, moisture content, and ash content measurements using the methods described in section 2.1 .

\subsection{Phytotoxicity tests}

Evaluation of the phytotoxicity of different soil amendment treatments was conducted using a lettuce (Lactuca sativa var. Parris Island Cos) (Sustainble Seed Co., Petaluma, CA) growth assay as previously described (Simmons et al., 2013). Amended soil for phytotoxicity assays was prepared using the simulated biosolarization methods described in section 2.2 with an incubation time of two weeks for all treatments. Control treatments consisted of soils that had not been subjected to simulated biosolarization, which included field soil without amendment and field soil freshly amended with compost and tomato- or white wine grape-pomace. Red wine grape pomace was excluded from phytoxicity testing, based on data from other experiments suggesting it is not as readily suitable as an amendment for biosolarization. seedling growth in each soil amendment treatment. Soil from each treatment was mixed 1:1 (v/v) with sand to promote drainage. Samples of each soil mixture were placed in germination trays containing cells that measured $3.81 \times 3.81 \mathrm{~cm}$ by $5.7 \mathrm{~cm}$ deep. Trays were incubated on a $37^{\circ} \mathrm{C}$ heating pad and were watered by misters for 1 min every hour spanning $9 \mathrm{hr}$ per day. At 0, 4 and 8 days of greenhouse incubation (representing varying in the soil. Five lettuce seeds were planted equidistant from one another in each cell at a 
depth of $1 \mathrm{~cm}$. Experimental units consisted of two adjacent cells (10 seeds total). Three replicate units were used for each treatment. Eight days after seeding, germination rates were determined by counting the number of seedlings that emerged from the soil in each unit. Eight days after sowing, seedlings were harvested, gently washed and photographed. Dry biomass yield was calculated by weighing the harvested seedlings from each unit after one day of drying at a $105^{\circ} \mathrm{C}$. Seedling root and shoot length measurements were determined from photographs using ImageJ software (National Institutes of Health, Bethesda, MD). from the aerobic bioreactor system were calculated from effluent concentration data by MATLAB software (Version R2012a, MathWorks, Natick, MA) according to an analysis method described previously (Simmons et al., 2013). The calculation of rate and cumulative gas production $\left(\mathrm{CO}_{2}\right.$ and $\left.\mathrm{H}_{2}\right)$ in the anaerobic bioreactor system was done via MicroOxymax Respirometer software (Version 1.0.1, Columbus Instruments, Columbus, $\mathrm{OH})$. linear fit function within MATLAB to fit empirical data to the following equation:

$$
\mathrm{cCER}=\mathrm{cCER}_{\max } \mathrm{t}\left(\mathrm{C}_{\text {half }}+\mathrm{t}\right)^{-1}
$$
where $\mathrm{cCER}_{\max }$ is the theoretical maximum of cCER $(\mathrm{mg} \mathrm{CO} / \mathrm{g}$ dry weight of amended soil), $\mathrm{C}_{\mathrm{half}}$ is a constant describing the length of time needed to achieve half of $\mathrm{cCER}_{\max }$ (days) and $t$ is the time post-lag phase (days). The lag time (days) was defined as the length of time required for cCER to exceed $0.2 \mathrm{mg} \mathrm{CO}_{2} / \mathrm{g}$ dry weight. Temperature elevation in soil, $\Delta \mathrm{T}$, was calculated as 


$$
\Delta \mathrm{T}=\mathrm{T}_{\text {treat }}-\mathrm{T}_{\text {con }}
$$

214 Where $\mathrm{T}_{\text {treat }}$ is the temperature measured in amended soil at a particular time point and $215 \mathrm{~T}_{\text {con }}$ is the average temperature measured across all control reactors at the same time 216 point. Peak temperature elevation, $\Delta \mathrm{T}_{\max }$, was defined as the maximum $\Delta \mathrm{T}$ observed while reactors were respiring. The area beneath $\Delta \mathrm{T}$ versus time plots (degree-days) was determined as a measure of prolonged temperature elevation in soil during simulated biosolarization. Degree-day values were calculated by using the trapezoidal rule to approximate the integral of $\Delta \mathrm{T}$ versus time plots over the period spanning the end of the lag phase up to the first 6 days of incubation, which captured the majority of soil respiration.

ANOVA with post-hoc Tukey's Honest Significant Difference test was used to compare mean response values across treatments. The familywise error rate equaled 0.05 for all comparisons. Statistical analyses were performed using JMP-pro software (version 11.0.0, SAS, Cary, NC).

\section{Results and discussion}

3.1 Organic matter utilization and gas evolution in soil microbial activity. The magnitude and duration of gas release provide measures of the overall intensity of microbial activity and the ability of microorganisms to rapidly consume amended and pre-existing organic matter. These are metrics that are related to biological heating of soil (Bradford et al., 2008) and soil acidification, both of which are potential mechanisms of pest inactivation during biosolarization. Carbon dioxide production was primarily observed under aerobic soil conditions (Fig. 2; Table 3). Most anaerobic and control treatments did not yield sufficient gas production to permit fitting 
of $\mathrm{cCER}_{\max }$ and $\mathrm{C}_{\text {half }}$ parameters. Among the aerobic treatments, tomato pomace yielded the greatest total amount of $\mathrm{CO}_{2}$, as indicated by a significantly larger $c \mathrm{CER}_{\max }$ value compared to other amendments. This was also true for the anaerobic treatments, where only tomato pomace showed appreciable $\mathrm{CO}_{2}$ production during the incubation period. Gas evolution kinetics also highlighted differences in the performance of each soil amendment (Table 3). $\mathrm{C}_{\text {half }}$ values indicated the time to exhaust half the expected maximum $\mathrm{CO}_{2}$ evolution potential. For aerobic treatments, white wine grape pomace had the most rapid gas evolution compared to the other amendments. $\mathrm{C}_{\text {half }}$ values for tomato pomace-amended soil were over 12 times greater than that for white wine grape pomace amendment, indicating soil microbial activity was sustained over a longer time. $\mathrm{C}_{\text {half }}$ was greatest for red wine grape pomace at over 9 days, which was significantly longer than that observed for white wine grape pomace. The relatively slow production of $\mathrm{CO}_{2}$ from soil with red wine grape pomace may stem from the composition of the pomace, which is enriched for lignocellulose due to other nutrients being removed during the wine fermentation process (Zheng et al., 2012). The need to deconstruct the recalcitrant structure of lignocellulose to release sugars may limit the rate of microbial activity on red wine grape pomace. Another explanation for the difference between red and white wine grape pomace respiration kinetics may relate to microbial inhibition caused by their different polyphenolic compositions (Katalinić et al., 2010). These data highlight differences in soil microbial activity for each amendment that could be relevant to biosolarization. In particular, the microbial activity kinetics could influence the duration of biosolarization needed to achieve pest inactivation. anaerobic conditions. The data show that both tomato pomace and white wine grape pomace amendment led to similar $\mathrm{H}_{2}$ production rates, although white wine grape pomace 
had a greater lag time (Fig. 3). In contrast, red wine grape pomace amendment did not show any $\mathrm{H}_{2}$ production. $\mathrm{H}_{2}$ evolution can accompany production of organic acids by anaerobic bacteria commonly associated with degradation of plant biomass (Levin et al., 2006). Accordingly, $\mathrm{H}_{2}$ evolution kinetics may indicate when organic acid production occurred for each organic matter amendment. Notably, after five days of anaerobic incubation, soil with red wine grape pomace exhibited methane production (data not shown). As methane is a potent greenhouse gas, these emissions may add to the difficulty of adapting red wine grape pomace for use as a soil amendment for biosolarization. Microbially-mediated gas production in soil corresponded with utilization of volatile solids in soil during simulated biosolarization. In agreement with gas evolution data, aerobic treatments showed significantly greater reduction in soil volatile solids compared to anaerobic treatments $(\mathrm{p}<0.001)$ (Table 4). Fermentation products, such as organic acids, may have accumulated in the anaerobic treatments and inhibited the soil microbial communities, which prevented further consumption of soil organic matter. More research is needed to determine how the amount of organic matter, both degradable and recalcitrant, remaining in soil following biosolarization may influence soil properties and recolonization of treated soil by both beneficial and pest microorganisms.

\subsection{Soil temperature changes during simulated biosolarization}

Thermal stress is a major determinate of weed seed and pathogen inactivation during biosolarization. Studies have shown that soil heating in the range of $40{ }^{\circ} \mathrm{C}$ to $60{ }^{\circ} \mathrm{C}$ can be very effective for pest control (Dahlquist et al., 2007; Etxeberria et al., 2011; Stapleton, 2000). In this study, the potential for biological heat generation to increase soil temperatures above that achieved through solar heating alone was assessed for different soil organic amendments. Since the relationship between temperature and soil pathogen 
inactivation time is known to be logarithmic in some cases (Pullman et al., 1981), an increase in soil temperature of 1 to $2{ }^{\circ} \mathrm{C}$ can have a major effect on the time to achieve inactivation.

Biological heating of soil from microbial metabolism of soil organic matter was quantified by measuring the peak temperature elevation achieved and the duration of elevated soil temperature for each soil amendment. Both aeration and amendment type affected the temperature profile in soils during simulated biosolarization (Fig.4). The aerobic treatments generally yielded greater soil temperature elevations compared to anaerobic treatments $(\mathrm{p}>0.0382)$. This is to be expected as aerobic respiration typically releases more energy per unit substrate than anaerobic respiration or fermentation. Soil amended with white wine grape pomace under aerobic conditions had a significantly higher $\Delta \mathrm{T}$-max than control soil, with peak temperature elevation reaching $2.32{ }^{\circ} \mathrm{C}$ over the control (Table 3). However, tomato pomace amendment under aerobic conditions had the most temporally-sustained soil temperature elevation, as indicated by a degree-day value of $6.27^{\circ} \mathrm{C} / \mathrm{day}$, which was signficantly greater than the control. In contrast, anaerobic treatments produced little biological heating. While soil with tomato pomace appeared to produce a brief increase in soil temperature (Fig. 4B), there were no significant differences in peak temperature elevation or cumulative heating for any amendments compared to the control under anaerobic conditions (Table 3).

Temperature elevation data aligned with respiration data for each amendment. The greatest peak temperature elevation, which was observed for white wine grape pomace under aerobic conditions during the first 1.5 days of incubation, agreed with the respiration kinetics data that showed the lowest $\mathrm{C}_{\text {half }}$ value for this amendment. The initial rapid increase in microbial activity in white wine grape pomace resulted in rapid heat 

pomace corresponded with similar trends found in the $\mathrm{CO}_{2}$ evolution rate data. Finally, the lack of significant biological soil heating for soil with red wine grape pomace may be explained by the repressed respiration rates with this amendment. From a heat generation perspective, both tomato- and white wine grape-pomaces showed promise as biosolarization amendments. Furthermore, these results demonstrated that amendment composition and aeration conditions heavily influence the potential for biological contributions to pest inactivation during biosolarization for various amendments, with biological heat generation only complimenting passive solar heating in areas of the soil containing sufficient microbial activity and oxygen to sustain aerobic respiration.

\subsection{Soil acidification}

In addition to soil temperature changes, fermentation products are a major determinate of anaerobic soil disinfestation (ASD) and biosolarization efficacy (Momma et al., 2006). In particular, production of organic acids that affect soil redox potential contributes to pest inactivation when soils are maintained in a saturated state (Butler et al., 2014). Simulated biosolarization data showed that aeration significantly affected $\mathrm{pH}$ change in biosolarized soil $(\mathrm{p}<0.001)$. For aerobic treatments, the $\mathrm{pH}$ increased for soils has been reported to contain twice the level of protein compared to white wine pomace (Zheng et al., 2012). The higher protein content of red wine pomace may have enhanced 
white wine grape pomace may be due to the high water soluble carbohydrate content of white wine grape pomace (Baumgärtel et al., 2007), which could have facilitated rapid microbial activity and consumption of the oxygen supplied to bioreactors. Subsequent development of anaerobic niches in the soil could have resulted in acid fermentation and $\mathrm{pH}$ depression. Acidification may also explain the relatively low $\mathrm{cCER}_{\max }$ observed for aerobic biosolarization of soil with white wine grape pomace. The drop in $\mathrm{pH}$ may have inhibited the soil microbial community and prevented complete consumption of the soil organic matter. The unique acidification of soil with white wine grape pomace under aerated conditions could be exploited for biosolarization if acidification is desired in soils where oxygen contamination is likely.

Under anaerobic conditions, $\mathrm{pH}$ decreased for soil amended with white wine grape pomace similar to aerobic treatments. However, in contrast to aerobic incubations, $\mathrm{pH}$ decreased for soil containing tomato pomace and increased moderately for red wine grape pomace in anaerobic incubations. In anaerobic conditions all amendments achieved a significantly lower $\mathrm{pH}$ relative to the control following treatment (Table 4). For tomato pomace and white wine grape pomace, $\mathrm{pH}$ values of 5 and below were achieved for the anaerobic condition. These $\mathrm{pH}$ levels have been shown to suppress common fungal and bacterial soil pathogens (Momma et al., 2006). Additional studies are needed to determine if combining elevated temperature with such acidification during biosolarization can enhance or accelerate pathogen inactivation. Unlike tomato- and white wine grapepomaces, which showed decreases in $\mathrm{pH}$ following anaerobic biosolarization, red wine grape pomace amendment led to soil becoming less acidic over the course of anaerobic biosolarization (Tables 2 and 4). This may be due to the low levels of water soluble carbohydrates in red wine grape pomace, which are consumed during the wine fermentation process, or to the presence of proteins which enhance ammonia production 

may not be sufficiently acidified to inactivate organic-acid consuming microorganisms, such as acetotrophic methanogenic archaea. The activity of such microorganisms could lead to removal of organic acids, production of ammonia, and increase soil $\mathrm{pH}$. The eventual production of methane that was uniquely observed during anaerobic treatment of soil with red wine grape pomace is consistent with this explanation.

\subsection{Soil treatment phytotoxicity}

While phytotoxicity is desirable for weed seed inactivation during biosolarization, residual phytotoxicity may be detrimental to crops that are subsequently planted in treated soils. Several metrics that captured germination and seedling growth effects were used to measure residual phytotoxicity at various times post-biosolarization (Fig. 5). As heat generation and soil acidification data indicated that red wine grape pomace may be less suitable as a biosolarization amendment, it was excluded from residual phytotoxicity testing. The results show that seeding immediately after the end of biosolarization had a negative effect on total biomass yield for soil that underwent anaerobic biosolarization (Fig. 5A). These results are likely due to residual organic acids and/or other reduced compounds in the anaerobic treatments, which is consistent with $\mathrm{pH}$ data. However, no significant negative effects on biomass yield were observed at or beyond 4 days postbiosolarization. Overall biomass yield is determined by the combined effect of germination rate and the growth of germinated seedlings. Immediately following biosolarization, anaerobically treated soils showed decreased germination rates, with white wine grape pomace being significantly lower than the control. These differences vanished by 4 days post-treatment (Fig. 5B). Notably, germination rates decreased over time in the soil-only control treatments. At 8 days post-treatment, many biosolarized soils 
exhibited significantly higher germination rates than the control. This could be a result of soil compaction or poor nutrition in the control soil, which was mitigated by the presence of organic matter in the biosolarized soils. Phytotoxicity was also apparent in measurements of seedling root length (Fig. 5C). For all treatments, planting immediately after biosolarization resulted in significantly stunted roots relative to soil-only controls. Some of these differences persisted up to 8 days post-biosolarization. However, no significant differences were found between the shoot length of seedlings from biosolarized soils and those from untreated controls both immediately following biosolarization and at 8 days post-treatment (Fig. 5D).

Data for total biomass yields agreed with yield results from previous biosolarization laboratory results with green waste compost (Simmons et al., 2013) and field trials with chicken compost (Gamliel and Stapleton, 1993b), showing that residual phytotoxicity to lettuce is rapidly eliminated from soils following biosolarization treatment. These data suggest that soil that has been biosolarized with tomato- or white wine grape-pomace also will be quickly restored to phytocompatibility. However, these results were obtained under ideal greenhouse conditions where potted, sandy-loam soil was well-drained and aerated. These conditions likely favored elimination of phytotoxic factors by leaching and/or volatilization. Additional work is needed to determine the rate of soil remediation for the range of environmental and edaphic conditions that may be encountered in commercial plant production.

\section{Conclusions}


412 pomace and tomato pomace led to significant soil temperature elevation under aerobic

413 conditions and significant $\mathrm{pH}$ decreases under anaerobic soil conditions. These changes

414 induced soil conditions that are consistent with those known to inactivate weed seeds and

415 microbial pathogens. Soil containing these amendments showed low residual phytotoxicity

416 following treatment. As a result, they warrant further pest inactivation investigations in

417 biosolarization field trials. Conversely, red wine grape pomace amendment did not lead to

418 significant soil heating or acidification and undesirable soil methanogenesis was observed,

419 indicating it is less suitable for biosolarization.

420

421

\section{Acknowledgments}

423

This work was funded by the California Department of Pesticide Regulation (grant

424 agreement number 14-PML-R004) and the National Science Foundation (CBET-1438694). 


\section{References}

Baumgärtel, T., Kluth, H., Epperlein, K., Rodehutscord, M., 2007. A note on digestibility and energy value for sheep of different grape pomace. Small Ruminant Research 67, 302-306. Bradford, M.A., Davies, C.A., Frey, S.D., Maddox, T.R., Melillo, J.M., Mohan, J.E., Reynolds, J.F., Treseder, K.K., Wallenstein, M.D., 2008. Thermal adaptation of soil microbial respiration to elevated temperature. Ecology Letters 11, 1316-1327.

Butler, D.M., Kokalis-Burelle, N., Albano, J.P., McCollum, T.G., Muramoto, J., Shennan, C., Rosskopf, E.N., 2014. Anaerobic Soil Disinfestation (ASD) Combined with Soil Solarization as a Methyl Bromide Alternative: Vegetable Crop Performance and Soil Nutrient Dynamics. Plant and Soil 378, 365-381.

Dahlquist, R.M., Prather, T.S., Stapleton, J.J., 2007. Time and temperature requirements for weed seed thermal death. Weed Science 55, 619-625.

Del Valle, M., Cámara, M., Torija, M.E., 2006. Chemical characterization of tomato pomace. Journal of the Science of Food and Agriculture 86, 1232-1236.

Etxeberria, A., Mendarte, S., Larregla, S., 2011. Thermal inactivation of Phytophthora capsici oospores. Revista Iberoamericana de Micología 28, 83-90.

Gamliel, A., Stapleton, J., 1993a. Characterization of antifungal volatile compounds evolved from solarized soil amended with cabbage residues. Phytopathology 83, 899-905.

Gamliel, A., Stapleton, J., 1993b. Effect of chicken compost or ammonium phosphate and solarization on pathogen control, rhizosphere microorganisms, and lettuce growth. Plant Disease 77, 886-891.

Huang, X., Wen, T., Zhang, J., Meng, L., Zhu, T., Cai, Z., 2014. Toxic organic acids produced in biological soil disinfestation mainly caused the suppression of Fusarium oxysporum $f$. $s p$. cubense. BioControl, 1-12.

Katalinić, V., Možina, S.S., Skroza, D., Generalić, I., Abramovič, H., Miloš, M., Ljubenkov, I., Piskernik, S., Pezo, I., Terpinc, P., 2010. Polyphenolic profile, antioxidant properties and antimicrobial activity of grape skin extracts of 14 Vitis vinifera varieties grown in Dalmatia (Croatia). Food Chemistry 119, 715-723.

Katan, J., 1981. Solar heating (solarization) of soil for control of soilborne pests. Annual Review of Phytopathology 19, 211-236.

Katan, J., DeVay, J.E., 1991. Soil solarization. cRC Press.

Lamers, J., Mazzola, M., Rosskopf, E., Kokalis-Burelle, N., Momma, N., Butler, D., Shennan, C., Muramoto, J., Kobara, Y., 2014. Anaerobic Soil Disinfestation for Soil Borne Disease Control in Strawberry and Vegetable Systems: Current Knowledge and Future Directions, VIII International Symposium on Chemical and Non-Chemical Soil and Substrate Disinfestation 1044, pp. 165-175.

Levin, D.B., Islam, R., Cicek, N., Sparling, R., 2006. Hydrogen production by Clostridium thermocellum 27405 from cellulosic biomass substrates. International Journal of Hydrogen Energy 31, 1496-1503.

Lichtfouse, E., Navarrete, M., Debaeke, P., Souchère, V., Alberola, C., Ménassieu, J., 2009. Agronomy for sustainable agriculture: a review. Springer.

López-Pérez, J.-A., Roubtsova, T., Ploeg, A., 2005. Effect of three plant residues and chicken manure used as biofumigants at three temperatures on Meloidogyne incognita infestation of tomato in greenhouse experiments. Journal of nematology $37,489$. 
Maione, M., Giostra, U., Arduini, J., Furlani, F., Graziosi, F., Lo Vullo, E., Bonasoni, P., 2013. Ten years of continuous observations of stratospheric ozone depleting gases at Monte Cimone (Italy) - Comments on the effectiveness of the Montreal Protocol from a regional perspective. Science of the Total Environment 445, 155-164.

Mallek, S.B., Prather, T.S., Stapleton, J.J., 2007. Interaction effects of Allium spp. residues, concentrations and soil temperature on seed germination of four weedy plant species. Applied Soil Ecology 37, 233-239.

Matteson, G.C., Jenkins, B., 2007. Food and processing residues in California: Resource assessment and potential for power generation. Bioresource technology 98, 3098-3105. McConnell, A., Eastwood, M., Mitchell, W., 1974. Physical characteristics of vegetable foodstuffs that could influence bowel function. Journal of the Science of Food and Agriculture 25, 1457-1464.

Momma, N., Yamamoto, K., Simandi, P., Shishido, M., 2006. Role of organic acids in the mechanisms of biological soil disinfestation (BSD). Journal of General Plant Pathology 72, 247252.

Pansu, M., Gautheyrou, J., 2007. Handbook of soil analysis: mineralogical, organic and inorganic methods. Springer.

Popp, J., Pető, K., Nagy, J., 2013. Pesticide productivity and food security. A review. Agronomy for Sustainable Development 33, 243-255.

Pullman, G., DeVay, J., Garber, R., 1981. Soil solarization and thermal death: a logarithmic relationship between time and temperature for four soilborne plant pathogens. Phytopathology 71, 959-964.

Simmons, C.W., Claypool, J.T., Marshall, M.N., Jabusch, L.K., Reddy, A.P., Simmons, B.A., Singer, S.W., Stapleton, J.J., VanderGheynst, J.S., 2014. Characterization of bacterial communities in solarized soil amended with lignocellulosic organic matter. Applied Soil Ecology 73, 97-104.

Simmons, C.W., Guo, H., Claypool, J.T., Marshall, M.N., Perano, K.M., Stapleton, J.J., VanderGheynst, J.S., 2013. Managing compost stability and amendment to soil to enhance soil heating during soil solarization. Waste Management 33, 1090-1096.

Stapleton, J., Molinar, R., Lynn-Patterson, K., McFeeters, S., Shrestha, A., 2005. Methyl bromide alternatives... Soil solarization provides weed control for limited-resource and organic growers in warmer climates. California agriculture 59, 84-89.

Stapleton, J.J., 2000. Soil solarization in various agricultural production systems. Crop Protection 19, 837-841.

Stapleton, J.J., Summers, C.G., Mitchell, J.P., Prather, T.S., 2010. Deleterious activity of cultivated grasses (Poaceae) and residues on soilborne fungal, nematode and weed pests. Phytoparasitica 38, 61-69.

Valiente, C., Arrigoni, E., Esteban, R., Amado, R., 1995. Grape pomace as a potential food fiber. Journal of Food Science 60, 818-820.

Yildiz, A., Benlioğlu, S., Boz, Ö., Benlioğlu, K., 2010. Use of different plastics for soil solarization in strawberry growth and time-temperature relationships for the control of Macrophomina phaseolina and weeds. Phytoparasitica 38, 463-473.

Zheng, Y., Lee, C., Yu, C., Cheng, Y.-S., Simmons, C.W., Zhang, R., Jenkins, B.M., VanderGheynst, J.S., 2012. Ensilage and bioconversion of grape pomace into fuel ethanol. Journal of Agricultural and Food Chemistry 60, 11128-11134. 


\section{Figure Captions}

Figure 1

Figure 2

Figure 3

Figure 4

Figure 5
Bioreactor systems for simulated solarization. Bioreactor conditions represent the anaerobic environment that may be encountered at lower soil depths where oxygen diffusion is limited and the aerobic environment that may occur closer to the soil surface due to oxygen diffusion through the tarp and from surrounding uncovered soil.

Carbon dioxide $\left(\mathrm{CO}_{2}\right)$ evolution in soil amended with compost and pomace . (A) Cumulative $\mathrm{CO}_{2}$ evolution (cCER) in the aerobic system, (B) $\mathrm{CO}_{2}$ evolution rate (CER) in the aerobic system, (C) cCER in the anaerobic system, (D) CER in the anaerobic system. Data represent the mean of four (aerobic) or three (anaerobic) replicate bioreactors.

Hydrogen gas $\left(\mathrm{H}_{2}\right)$ evolution in soil amended with compost and pomace under anaerobic conditions. (A) Cumulative $\mathrm{H}_{2}$ evolution, (B) $\mathrm{H}_{2}$ evolution rate. Data represent the mean of three replicate bioreactors.

Soil temperature elevation during simulated biosolarization of soil amended with compost and pomace in the (A) aerobic system and (B) anaerobic system. Temperature elevation is relative to control bioreactors lacking pomace amendment. Data represent the mean of four (aerobic) or three (anaerobic) replicate bioreactors. Data obtained during the initial heating of bioreactors from ambient temperature to the incubator temperature (approximately 0.5 days) are not shown.

Residual phytotoxicity of soils at 0,4 , and 8 days following simulated biosolarization. Phytotoxicity indicators included (A) total biomass yield, (B) germination rate, (C) seedling root length and (D) seedling shoot length. Con, control soil without amendment or biosolarization; TP con, 5\% tomato pomace in soil without biosolarization; WP con, $5 \%$ white wine grape pomace in soil without biosolarization; $\mathrm{TP}$ an, $5 \%$ tomato pomace in compost-amended soil following anaerobic biosolarization; TP ae, 5\% tomato pomace in compost-amended soil following aerobic biosolarization; 
WP an, 5\% white wine grape pomace in compost-amended soil following anaerobic biosolarization; WP ae, $5 \%$ white wine grape pomace in compostamended soil following aerobic biosolarization. Within each seeding day, values not connected by the same letter are significantly different $(\alpha=0.05)$.

Table 1 Properties of soil and soil amendments.

\begin{tabular}{cccccc}
\hline Component & $\begin{array}{c}\text { Moisture content } \\
(\mathrm{g} \text { water/g DS })\end{array}$ & $\begin{array}{c}\text { WHC (g water/g } \\
\mathrm{DS})\end{array}$ & $\mathrm{VS}(\% \mathrm{DS})$ & $\mathrm{pH}$ & $\begin{array}{c}\text { Bulk density } \\
(\mathrm{g} / \mathrm{mL})\end{array}$ \\
\hline Soil & $0.0115 \pm 0.006$ & $0.261 \pm 0.008$ & $98.13 \pm 0.26$ & $7.03 \pm 0.07$ & $1.36 \pm 0.12$ \\
$\begin{array}{c}\text { White wine } \\
\text { grape pomace }\end{array}$ & $0.170 \pm 0.005$ & $1.270 \pm 0.081$ & $5.91 \pm 1.26$ & $4.25 \pm 0.03$ & $0.78 \pm 0.16$ \\
$\begin{array}{c}\text { Tomato pomace } \\
\begin{array}{c}\text { Red wine grape } \\
\text { pomace }\end{array}\end{array}$ & $0.055 \pm 0.005$ & $3.551 \pm 0.256$ & $4.46 \pm 1.02$ & $4.53 \pm 0.03$ & $0.40 \pm 0.09$ \\
$\begin{array}{c}\text { Green waste } \\
\text { compost }\end{array}$ & $0.080 \pm 0.003$ & $1.341 \pm 0.093$ & $56.79 \pm 2.25$ & $8.00 \pm 0.07$ & $0.54 \pm 0.14$ \\
\hline
\end{tabular}

Values are given as mean \pm standard deviation $(n=4)$. DS, dry solids; WHC, water holding capacity; VS, volatile solids. 
Table 2 Properties of amended soil prior to simulated biosolarization.

\begin{tabular}{|c|c|c|c|}
\hline Mixture (\% DS) & $\begin{array}{c}\text { Moisture content (g } \\
\text { water/g DS) }\end{array}$ & VS (\%DS) & $\mathrm{pH}$ \\
\hline $\begin{array}{c}98 \% \text { Soil }+2 \% \text { Green } \\
\text { waste }(\mathrm{GW}) \\
\text { Compost (control) }\end{array}$ & $0.137 \pm 0.001$ & $98.1 \pm 0.5$ & $7.38 \pm 0.07$ \\
\hline $\begin{array}{c}93 \% \text { Soil }+2 \% \text { GW } \\
\text { Compost }+5 \% \text { White } \\
\text { wine grape pomace }\end{array}$ & $0.170 \pm 0.005$ & $93.0 \pm 0.3$ & $5.75 \pm 0.03$ \\
\hline $\begin{array}{c}93 \% \text { Soil }+2 \% \text { GW } \\
\text { Compost }+5 \% \text { Tomato } \\
\text { pomace }\end{array}$ & $0.265 \pm 0.008$ & $92.9 \pm 0.8$ & $6.31 \pm 0.03$ \\
\hline $\begin{array}{l}93 \% \text { Soil }+2 \% \text { GW } \\
\text { Compost }+5 \% \text { Red } \\
\text { wine grape pomace }\end{array}$ & $0.139 \pm 0.002$ & $94.1 \pm 0.3$ & $4.46 \pm 0.04$ \\
\hline
\end{tabular}

Values are given as mean \pm standard deviation $(n=4)$. DS, dry solids; VS, volatile solids. 
Table 3 Gas evolution kinetics in amended soils during simulated biosolarization.

\begin{tabular}{|c|c|c|c|c|c|c|}
\hline System & Mixture & $\Delta \mathrm{T}-\max \left({ }^{\circ} \mathrm{C}\right)$ & $\begin{array}{c}\text { Degree-days } \\
\left.\text { ( }{ }^{\circ} \mathrm{C} / \text { days }\right)\end{array}$ & $\begin{array}{l}\text { Lag Time } \\
\text { (days) }\end{array}$ & $\begin{array}{c}\mathrm{cCER}_{\max }\left(\mathrm{mg} \mathrm{CO} \mathrm{CO}_{2} / \mathrm{g}\right. \\
\mathrm{DS})\end{array}$ & $\mathrm{C}_{\text {half }}$ (days) \\
\hline \multirow[t]{3}{*}{ Aerobic } & $\begin{array}{c}\text { Soil }+2 \% \text { Green waste }(\mathrm{GW}) \\
\text { compost }+5 \% \text { White wine } \\
\text { grape pomace }\end{array}$ & $2.32 \pm 0.34(\mathrm{~A})$ & $4.225 \pm 1.044(\mathrm{~A}, \mathrm{~B})$ & $1.80 \pm 0.09(\mathrm{~B})$ & $9.90 \pm 2.12(\mathrm{~B}, \mathrm{C})$ & $0.33 \pm 0.05(\mathrm{~B})$ \\
\hline & $\begin{array}{c}\text { Soil }+2 \% \text { GW compost }+5 \% \\
\text { Tomato pomace }\end{array}$ & $1.94 \pm 0.65(\mathrm{~A}, \mathrm{~B})$ & $6.268 \pm 2.165(\mathrm{~A})$ & $1.83 \pm 0.05$ (B) & $66.77 \pm 3.64(\mathrm{~A})$ & $\begin{array}{l}4.19 \pm 0.78 \\
(\mathrm{~A}, \mathrm{~B})\end{array}$ \\
\hline & $\begin{array}{c}\text { Soil }+2 \% \text { GW compost }+5 \% \\
\text { Red wine grape pomace }\end{array}$ & $0.11 \pm 1.48$ (B) & $-0.056 \pm 2.728(\mathrm{~B})$ & $0.70 \pm 0.14(\mathrm{C})$ & $27.29 \pm 18.15$ (B) & $9.41 \pm 5.13$ (A) \\
\hline \multirow[t]{3}{*}{ Anaerobic } & $\begin{array}{c}\text { Soil }+2 \% \mathrm{GW} \text { compost }+5 \% \\
\text { White wine grape pomace }\end{array}$ & $0.58 \pm 1.31$ (a) & $-0.903 \pm 1.952$ (a) & ND & ND & ND \\
\hline & $\begin{array}{c}\text { Soil }+2 \% \text { GW compost }+5 \% \\
\text { Tomato pomace }\end{array}$ & $0.69 \pm 0.72$ (a) & $1.320 \pm 4.328$ (a) & $2.14 \pm 0.09$ (A) & $1.19 \pm 0.41(\mathrm{C})$ & $0.38 \pm 0.15$ (B) \\
\hline & $\begin{array}{c}\text { Soil }+2 \% \mathrm{GW} \text { compost }+5 \% \\
\text { Red wine grape pomace }\end{array}$ & $-0.19 \pm 0.83$ (a) & $-2.948 \pm 3.163$ (a) & ND & ND & ND \\
\hline
\end{tabular}

Values are given as mean \pm standard deviation ( $n=4$ for aerobic, $n=3$ for anaerobic). Within each column, values not followed by the same letter are significantly different $(\alpha=0.05)$. DS, dry solids; ND, value not determined due to insufficient saturation behavior in gas production data. For each response, capital letters refer to comparisons within aerobic treatments and lowercase letters indicate comparisons within anaerobic treatments. 
Table 4 Properties of amended soil following simulated biosolarization.

\begin{tabular}{|c|c|c|c|c|}
\hline System & Mixture & moisture content (g water/g DS) & Final VS reduction (DS\%) & Final pH \\
\hline \multirow[t]{4}{*}{ Aerobic } & $\begin{array}{l}\text { Control - Soil }+2 \% \\
\text { Green waste }(\mathrm{GW}) \\
\text { compost }\end{array}$ & $0.151 \pm 0.001$ & $7.63 \pm 7.87(\mathrm{~B})$ & $7.76 \pm 0.02$ (B) \\
\hline & $\begin{array}{l}\text { Soil + } 2 \% \text { GW compost } \\
+5 \% \text { White wine grape } \\
\text { pomace }\end{array}$ & $0.258 \pm 0.005$ & $29.37 \pm 11.24$ (A) & $4.42 \pm 0.08(\mathrm{C})$ \\
\hline & $\begin{array}{c}\text { Soil }+2 \% \text { GW compost } \\
+5 \% \text { Tomato pomace }\end{array}$ & $0.202 \pm 0.008$ & $34.65 \pm 3.43(\mathrm{~A})$ & $8.28 \pm 0.11(\mathrm{~A})$ \\
\hline & $\begin{array}{c}\text { Soil }+2 \% \text { GW compost } \\
+5 \% \text { Red wine grape } \\
\text { pomace }\end{array}$ & $0.131 \pm 0.044$ & $24.31 \pm 3.10(\mathrm{~A}, \mathrm{~B})$ & $8.25 \pm 0.16$ (A) \\
\hline \multirow[t]{4}{*}{ Anaerobic } & $\begin{array}{l}\text { Control }- \text { Soil }+2 \% \\
\text { GW compost }\end{array}$ & $0.120 \pm 0.003$ & $4.01 \pm 7.96$ (a) & $8.01 \pm 0.01$ (a) \\
\hline & $\begin{array}{c}\text { Soil }+2 \% \text { GW compost } \\
+5 \% \text { White wine grape } \\
\text { pomace }\end{array}$ & $0.210 \pm 0.080$ & $6.39 \pm 6.54$ (a) & $5.00 \pm 0.02(\mathrm{c})$ \\
\hline & $\begin{array}{c}\text { Soil }+2 \% \text { GW compost } \\
+5 \% \text { Tomato pomace }\end{array}$ & $0.240 \pm 0.040$ & $3.34 \pm 5.83$ (a) & $4.68 \pm 0.08(\mathrm{~d})$ \\
\hline & $\begin{array}{c}\text { Soil }+2 \% \text { GW compost } \\
+5 \% \text { Red wine grape } \\
\text { pomace }\end{array}$ & $0.170 \pm 0.010$ & $2.39 \pm 6.40$ (a) & $5.42 \pm 0.07$ (b) \\
\hline
\end{tabular}

Values are given as mean \pm standard deviation. Within each column, values not connected by the same letter are significantly different $(\alpha=0.05)$. VS; volatile solids, dry solids. For each response, capital letters refer to comparisons within aerobic treatments and lowercase letters indicate comparisons within anaerobic treatments. 
Fig. 1

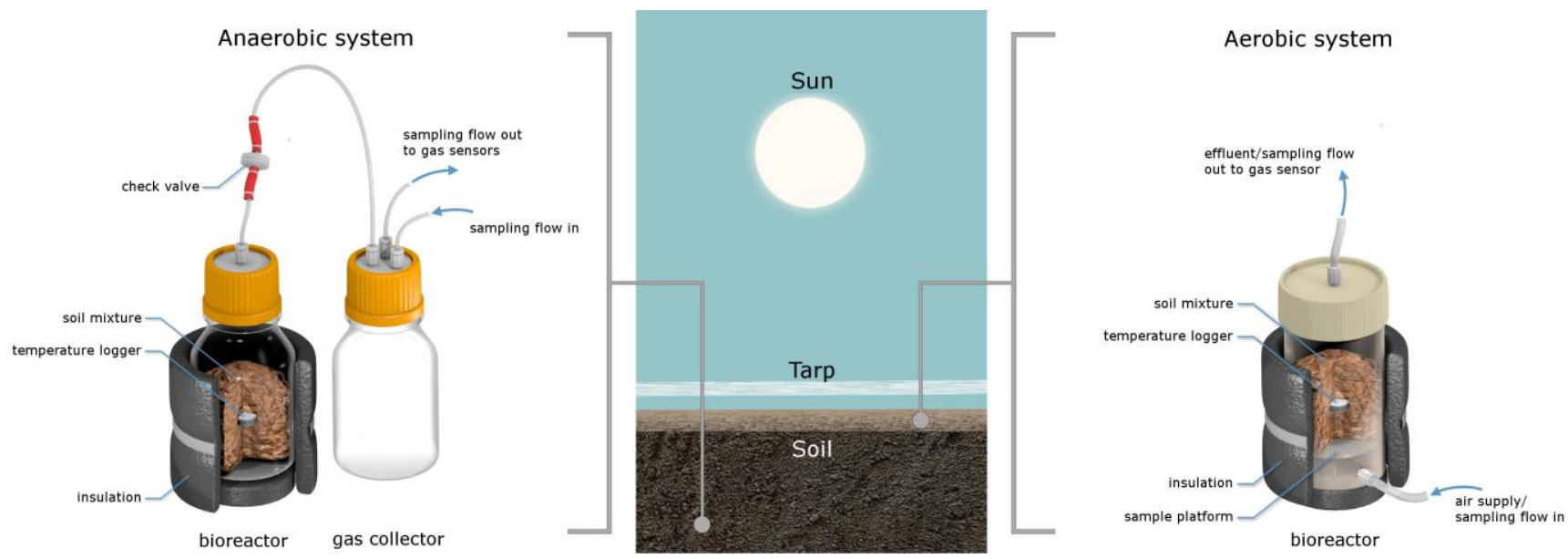


Fig. 2.

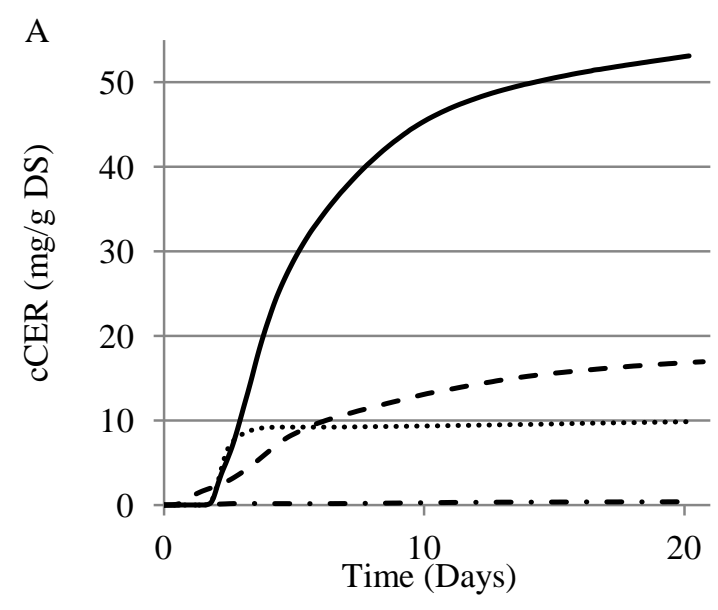

- - Control

Tomato

White wine grape - - - Red wine grape

C

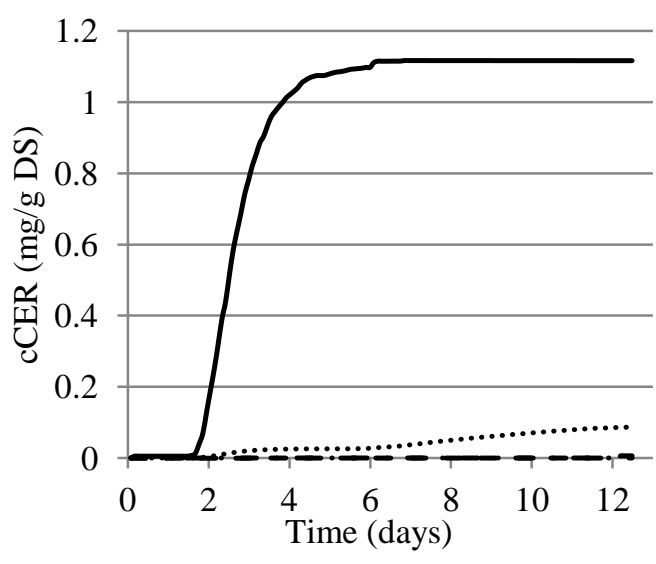

- - Control

- Tomato

....... White wine grape $\quad$ - - - Red wine grape
B
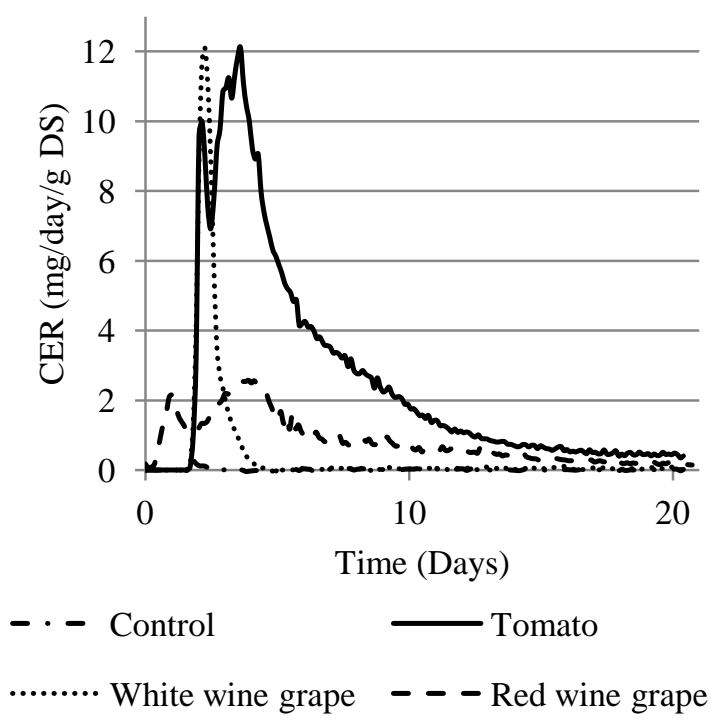

D

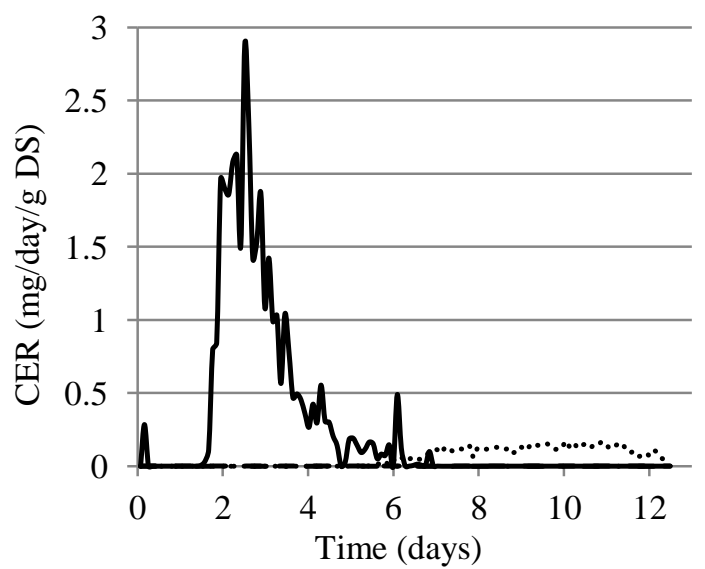

- - Control Tomato

White wine grape $\quad--$ Red wine grape 
Fig. 3.
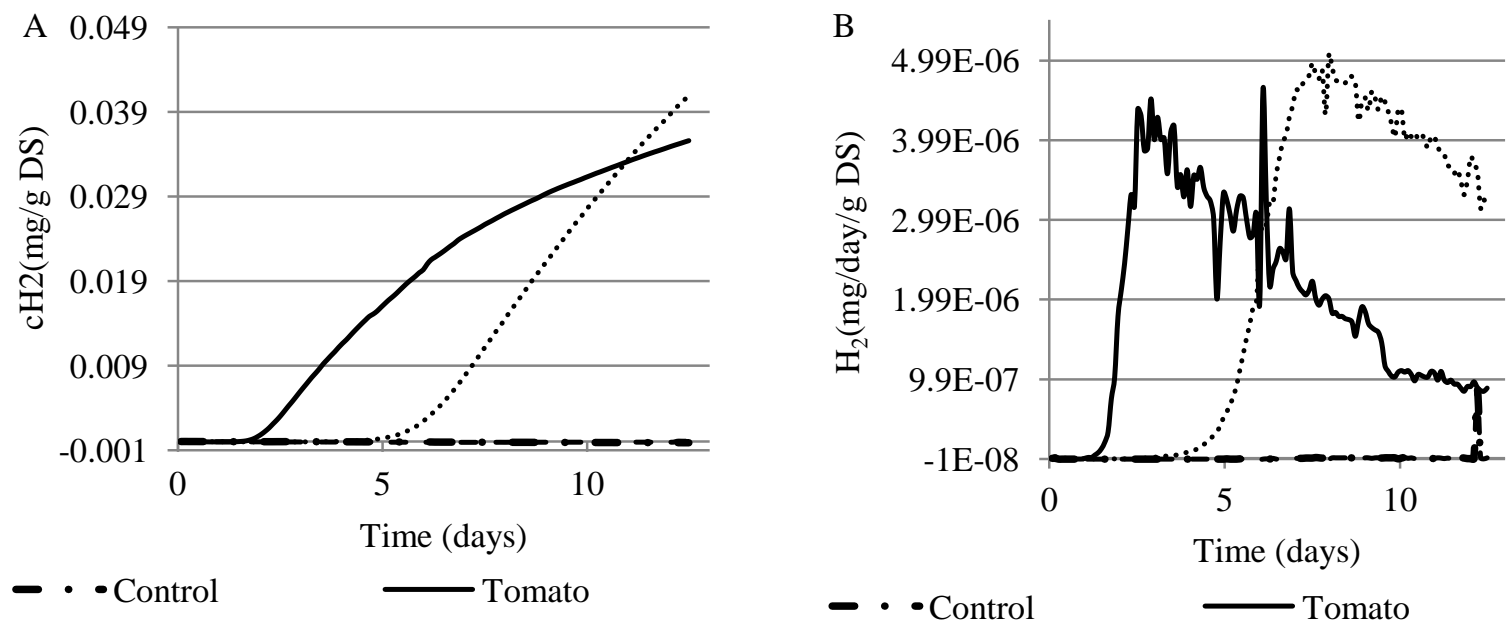

White wine grape - - - Red wine grape

White wine grape - - - Red wine grape 
Fig. 4.

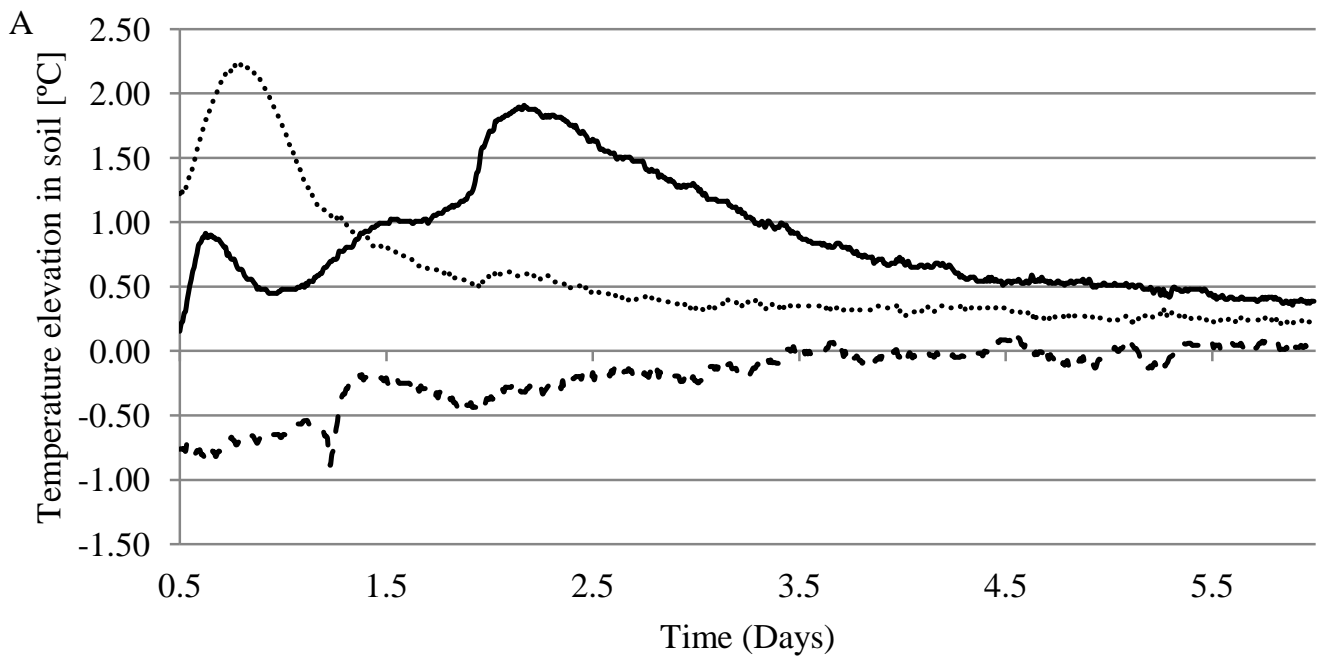

— Tomato $\quad . . . . . .$. White wine grape $\quad$ - - - Red wine grape

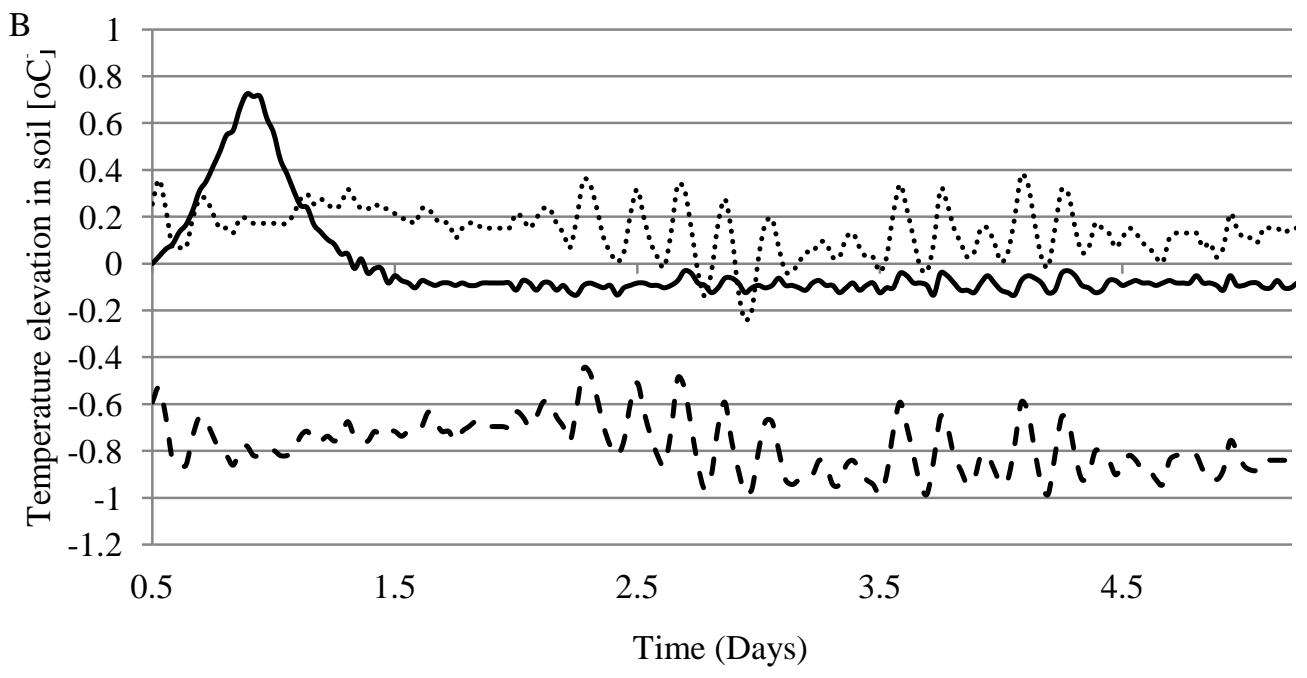

Tomato $\quad \cdots \cdots . . .$. White wine grape $\quad---$ Red wine grape 
Fig. 5.

A

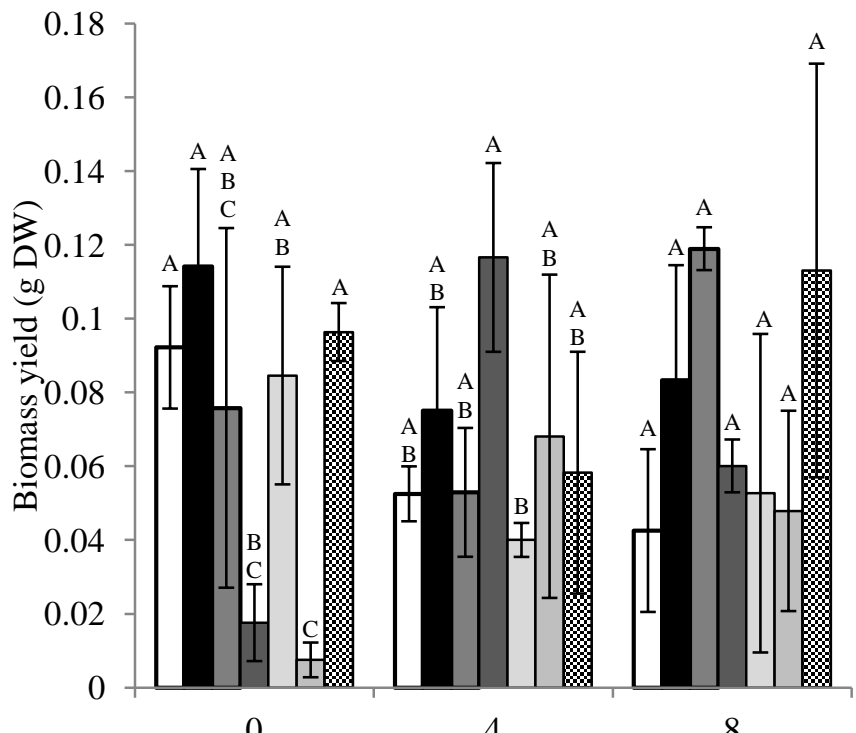

口Con

$\square 5 \% \mathrm{TP}$ ae

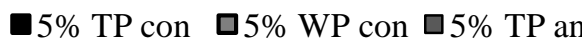

$\square 5 \% \mathrm{WP}$ an $\quad$ $5 \% \mathrm{WP}$ ae

C

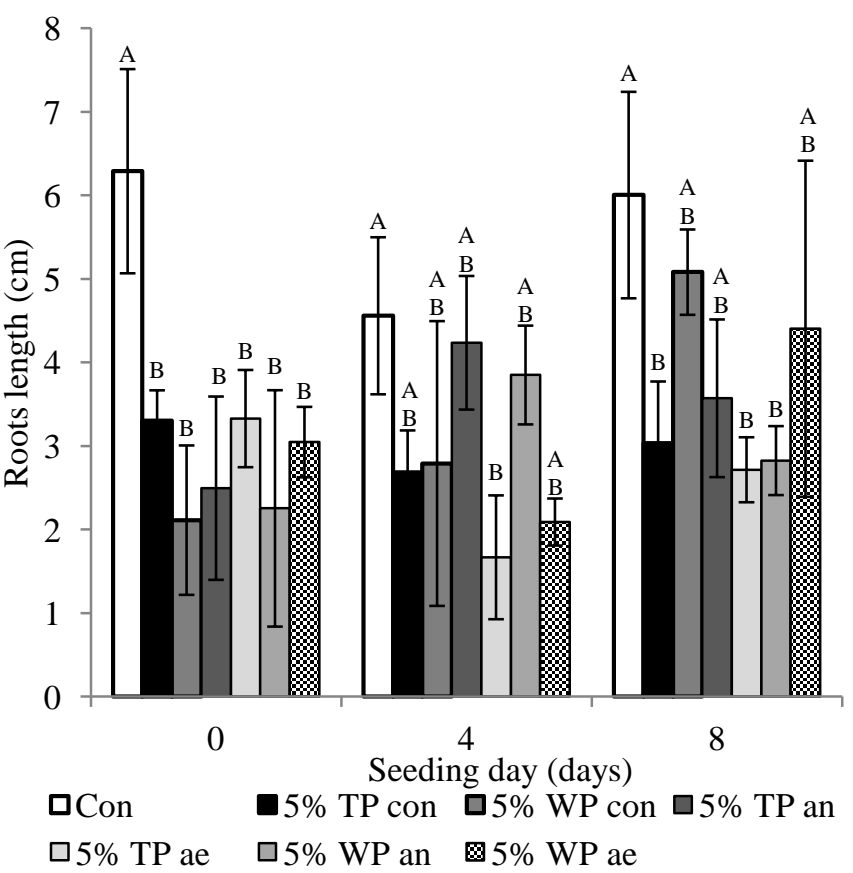

B

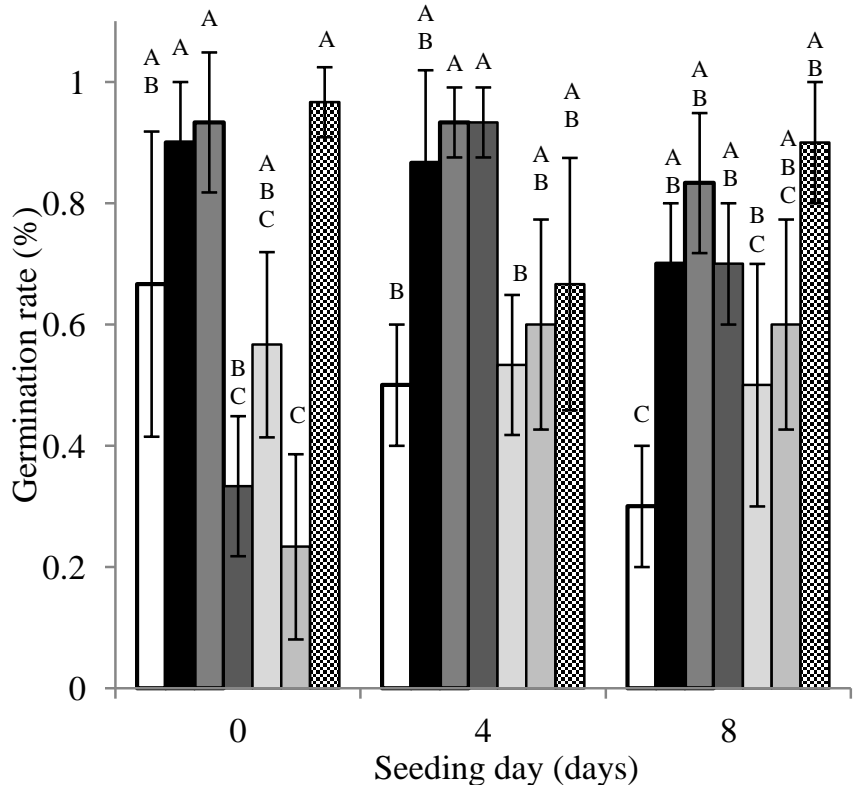

$\square$ Con $\square 5 \% \mathrm{TP}$ ae

5\% TP con 5 5\% WP con

$\square 5 \% \mathrm{WP}$ an $\quad 0 \% \mathrm{WP}$ ae

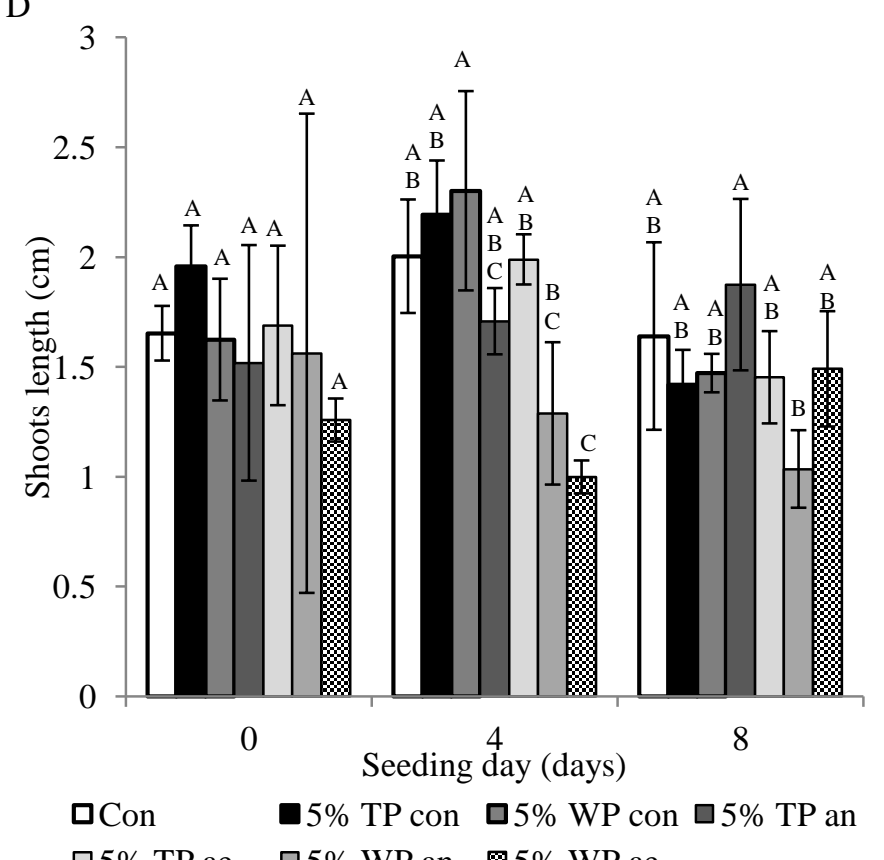

$\square 5 \%$ TP ae

$\square 5 \% \mathrm{WP}$ an $⿴ 囗 5 \% \mathrm{WP}$ ae 


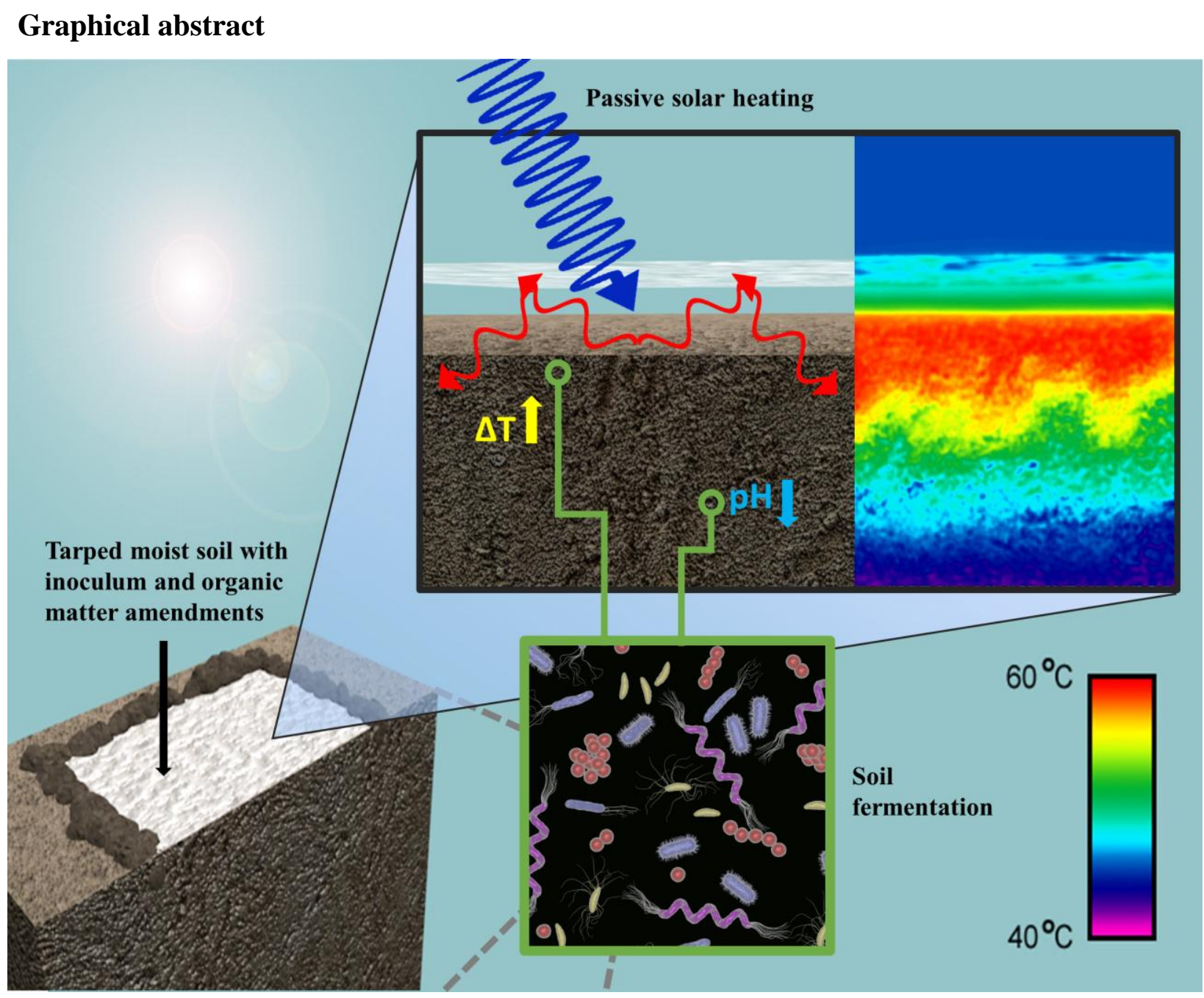

